\title{
The Impact of 4Ps Marketing Mix in Tourism Development in the Mountain Areas: A Case Study
}

\author{
Submitted 13/01/21, $1^{\text {st }}$ revision 12/02/21, $2^{\text {nd }}$ revision 28/02/21, accepted 27/03/21
Rehmat Karim ${ }^{1}$, Normah Abdul Latip ${ }^{2}$, Azizan Marzuki ${ }^{3}$, Sajjad Haider ${ }^{4}$, Memoona Nelofar ${ }^{5}$, Faqeer Muhammad ${ }^{6}$

\begin{abstract}
:
Purpose: This research is aimed to find out the relationship of marketing mix 4Ps (Price, Product. Process and Promotion) in tourism development in the mountain areas of GilgitBaltistan, Pakistan.

Methodology: To carry out the current study, a total of 509 self-administered questionnaires were distributed among the tourists to collect the data which was analysed by using SPSS and Partial Least Square (PLS). PLS-SEM was applied to find out the relationship between variables and test the strength of model.

Findings: The key findings are consistent with other studies while price mix and promotion mix are in contrast from others showing insignificant relationship in tourism development. There is evidence from the results that tourists are not concerned about the expenses which include mountaineering royalty fee, trekking royalty fee and other expenses while they tour to mountain areas. Therefore, it can be argued that price becomes less important for tourists to be considered, so, the relationship of price mix with the tourism development is insignificant. Another argument may come up regarding promotion mix that traditional advertisements have become obsolete now and majority of tourists use social media as it is also evidenced in the study that majority of tourists get information from social media sources, therefore, traditional promotion mix has no influence on attracting tourist towards the destinations.

Practical Implication: In addition to the contribution to existing body of knowledge, this study helps policy makers and managers of tourism sector to formulate proper plans by considering tourism marketing strategies for the development of tourism in mountain areas of Pakistan.
\end{abstract}

Originality/Values: This study contributes to find out the relationship of 4Ps-marketing mix with tourism development in the mountain areas of northern Pakistan.

Keywords: Tourism development, product, price, promotion, process, Pakistan.

JEL codes: M31, M37.

Paper type: Research article.

\footnotetext{
${ }^{1}$ Corresponding Author, Karakoram International University, Gilgit-Baltistan, Pakistan, and Universiti Sains Malaysia, Penang, Malaysia, rehmat@kiu.edu.pk;

${ }^{2}$ Universiti Sains Malaysia, Penang, Malaysia

${ }^{3}$ Universiti Sains Malaysia, Penang, Malaysia

${ }^{4}$ Karakoram International University, Gilgit-Baltistan, Pakistan

${ }^{5}$ Karakoram International University, Gilgit-Baltistan, Pakistan

${ }^{6}$ Karakoram International University, Gilgit-Baltistan, Pakistan
} 


\section{Introduction}

For the last five decades, tourism marketing approaches were dependent on international tourism trends and on the demand and supply of tourism and service sector while the application of marketing approaches in tourism industry were depended on the countries' industrial policies and consideration of travel and tourism in their sectoral domains. Firstly, tourism marketing approaches and orientation was accepted by airline sector and hotel group chains then gradually in other sub sectors of tourism industry (Patalkova, 2012).

Tourism marketing was defined as "the movement of people from and to besides their temporary stay at places away from their usual residents and identifying, anticipating and satisfying customer requirements and profitability" (Mwinuka, 2017). Branton (1969) and Wilson (1972) underlined the differentiation between tangible and intangible characteristics of service-related marketing.

Many researchers (Blois, 1974; Bessom and Jackson, 1975; Shostack, 1977) emphasized on proposing frameworks related with special characteristics of tourism and service marketing and proposed various alternate models and methodologies during the 70 's. Gradually the service marketing attained a distinctive position in the field of marketing as sub-discipline due to the reasons that after industrialization, service sector in the west became major contributor of national economic and corporate incomes.

Secondly, service-related products became augmented like physical products in the shape of hotels, airlines, and its support sector. Thus, service has important contribution in product diversity and giving an edge in competitive advantage (Kotler et al., 2001; Jobber, 2001; Constantinides, 2006). Jamal and Camargo, (2014) highlighted the significant role of marketers and destination manager who facilitate the tourism development by keeping in their marketing plans and processes (Mwinuka, 2017) meaning that marketing is key element to design strategies and proper communication for targeting the desired tourists' market to increase income for the destination (Donohoe, 2012).

Lei et al. (2014) stressed on academic researchers to identify the discourse on tourism marketing as they argued that marketing is key element to improve the ultimately aims to develop tourism. Hinch et al. (2016) also argued that little academic research is available concentrating on tourism marketing and its role in destination tourism development (Mwinuka, 2017). In tourism marketing, overall tourist experience is packaged in one brand instead of selling individual products like it happened in tangible industrial products (Liu and Chou, 2016), thus different tourism related business organizations use various channels and techniques of communication and promotion to sell the tourism destination (Avraham and McMillan, 2016). 


\section{Literature Review}

\subsection{Marketing Mix (4Ps)}

Dissemination of the tourism destination related information brought to the market through advertisement and promotion which fill the gap of tourists' demand and supply of services to them and draws the attention of consumer to visit the destination (Wijayanti and Ike-Janita, 2016). They further highlighted that marketing plays important role in developing the tourism destination quality, therefore, it is required to identify the relationship of tourism marketing with destination development. In this connection, its important components are vital to properly incorporate in the marketing strategies so that tourism can be developed at the destination (Sharma and Hazarika, 2017). Mehrdad, Firozeh, and Negar (2011) assessed the relationship between marketing mix and tourism development with different mix Scope, Site, Synergy and System (4s).

Many experts and professionals of marketing field believe that mix is the instrument of planning for operational marketing and it suits the transactional operations in the practice (Grönroos, 1994) whereas research studies with empirical data related to direct input in the business profitability of organizations is limited but still many researchers recognized the contribution of marketing mix (4Ps) for the success of its effective planning and management by conceptualizing at different level (Sriram and Sapienza, 1991; Romano and Ratnatunga, 1995; Coviello et al., 2000). According to Constantinides (2006) "a large-scale study carried out among executives of 550 Dutch companies revealed that about $70 \%$ of the companies surveyed apply formal marketing planning as basis of their operational marketing plans but responsibility for the Mix decisions is divided among different departments". Majority of business managers trust to include the 4P concept of marketing mix in the business-related operations.

\subsubsection{Product Mix}

According to Armstrong and Kotler (2006), a product can be defined as anything offered to a market for attention, acquisition, use, or consumption with the aim to satisfy the wants or needs of people. As far as services are concerned, according to Hirankitti, Mechinda, and Manjing (2009) the product offered in respect of services can be explained based on two components: (1) The core services aimed at providing core benefit; (2) The secondary services which represent both the tangible and augmented product levels. Secondary services refer to the manner of delivery of the services. Ferrell (2005) opines that the product is the core of the marketing mix strategy where retailers can offer unique attributes with products quite different from their competitors.

According to Borden (1984) product is characterized by quality, design, features, brand name and sizes (Muala, 2012). In the context of tourism, the destination might be the product, made up of private and public goods, or it might be the 
"industry" element, such as an attraction, accommodation service or tour operator. These elements can be public or private. The provider's level of control over the public element of the product will be more limited relative to the private element.

Weaver and Lawton (2010) suggest that the tourism manager will have little control over number of elements or responsibility for elements such as untidy streets, unfriendly residents, and inclement weather, and so forth. However, public-private partnership may help in reducing some of such negative effects (Pomering et al., 2011). The influence of host community may also help in improving the product if they make the tourism manager accountable through certain obligations with an objective to enhance mutual collaboration. It is understood that weather is uncontrollable, however tourists and residents can benefit from collaborative efforts and improve the physical and social environments (Pomering et al., 2011).

\subsubsection{Price Mix}

According to Kotler at al. (2008) price is the value of any service which service providers charge, and consumers pay to compensate it. Due to the intangible nature of services, price is a major quality indicator where other information is not lacking or absent (Zeithaml, 1981). Price is considered as the most important measurement of repurchase intentions (Oh, 2000; Parasuraman and Grewal, 2000). It has been proven therefore, that customers usually buy products based on price rather than other attributes (Peter and Donnely, 2007; Muala, 2012). Price is the most important element in marketing strategy as it generates revenue, while all the other elements in the marketing mix are costs. The marketing mix variable changes so quickly where competitors can react equally fast. Just relying on aggressive pricing without cost advantage is not a safe strategy (Lynch, 2000). While fixing prices, marketers and managers should pay attention to pricing policies which may encourage off-season and non-peak period sales, longer stays, group business and the sale of package plans (combination of room, meals, and recreational facilities). Pricing can be either market-orientated or, competitor-orientated but the later one may have severe disadvantages so the pricing must be based on marketing-orientated considerations. For example, one must consider price-quality relationships, market intelligence, clarity, value to the customer, product line pricing, competition, negotiating margins, effect on retailer political factors, distributors, and costs (Stremersch and Tellis, 2002).

\subsubsection{Promotion Mix}

Promotion mix is defined as "sales promotion, advertising, personal selling, public relations and direct marketing" (Borden, 1984) cited in (Muala and Qurneh, 2012). "Promotion refers to the decision of relating the product to the target market and persuade customers to buy it" (Lovelock, Patterson, and Walker, 1998) cited in (Muala and Qurneh, 2012). Communication strategy or program is vital for an effective promotional activity as it plays some important roles such as, providing the required information or advice, persuading target customers about the merits of products, and enticing them to take action (Lovelock and Wright, 2002). 
Promotion can be done through various activities such as advertising, sales promotions, personal selling, and publicity. All these strategies have the power to influence consumer's thinking pattern, emotions, as well as their experience. Communication should be done by marketers keeping in mind that it (1) offers clear messages about their products, and (2) appears in media that is commonly used by target groups (Munusamy and Hoo, 2008). Promotion in other words is a selling technique to enrich the marketing program, involving strong communication.

Promotion is crucial as it guides and advises the customer to act in terms of using a product and benefiting from it. Promotional messages are provided to target group either by individual salespeople, T.V, radio, or other means such as internet, magazine, and press (Muala and Qurneh. 2012). Promotional activities are aimed at supporting the competitive advantage of increasing demand for tourism while using the right promotional mix. This is thought to be the main element in the promotion mix to influence the thinking and decisions of target customer. Many models have discussed the advertising process for tourism promotion in different manners. Yeshin (1998) described the most influential one i.e., called the AIDA model which clearly identifies the stage of the communications process for promotion. This model has gained greater attention and appreciation because of its effectiveness and efficiency as a tool for promotion.

\subsubsection{Process Mix}

Process is normally defined as the implementation of action and function that has the potential to increase value for products with low cost and high advantage to customer. This is more important for service than for goods. According to Hirankitti et al. (2009) the speed of the process of any service and the movement of the service providers are vivid to customers and that is the basis customer satisfaction. In products and services, the, process management is aimed to make sure the availability and persistence of quality. In the face of continuous consumption and production it is a tall order to balance demand for services with the supply part (Magrath, 1986). It is a fact that the design and the implementation of products are key to the creation and delivering of product (Muala and Qurneh, 2012). The decisions made therein essentially affects the quality of services delivered. For example, a restaurant is quite different from a self-service cafeteria. Marketing managers need to understand what sort of service is needed in a particular scenario and how much that is accepted. Process means how the service is assembled, the "actual procedures, mechanisms, and flow of activities by which the service is delivered - the service delivery and operating systems" (Zeithaml et al., 2006).

\section{Research Design and Methodology}

This research design is intended to assess the perspectives about impacts of Marketing Mix on tourism development in the Central Karakoram National Park, in the opinion of foreign and domestic tourists. Therefore, quantitative research method with the background of cross-sectional method is used in this research. Probability 
sampling method was used by employing simple random sampling (SRS) approach. Simple random sampling is a basic sampling technique, group of samples were selected from large number of tourists travelling to the central Karakoram national park. The central Karakoram national park is scattered around 10000 sq. km which covers the boundaries of five districts and there are multiple entry points from various locations.

Thus, simple random sampling is a fair way to approach the sample group. By using this method researcher ensures that the equal chance is given to the sample units. Self-administered questionnaire was used as key research instrument to collect the data from tourist (foreign and domestic). The instrument was thoroughly processed by checking the reliability, internal consistency, and validity as it is one of the requirements of survey research. As this research aims to investigate the relationship of tourism development regarding marketing mix (4Ps: Product, Price, Process and Promotion), SPSS-21 and Smart PLS program3 packages were used to process and analyse the attained questionnaires survey-based data in the Central Karakoram National Park, Gilgit-Baltistan, Pakistan. Partial Least Square Structural Equation Modelling (PLS-SEM) was used to evaluate the variables set for the study. PLSSEM can be helpful for formative as well as reflective variables to find the causeand-effect relationship. It is considered as nonparametric method; therefore, PLSSEM is commonly used to assess variance-based research models in the field of social sciences (Hair et al., 2012; Hussain et al., 2018; Karim et al., 2021).

Figure 1. Research Framework

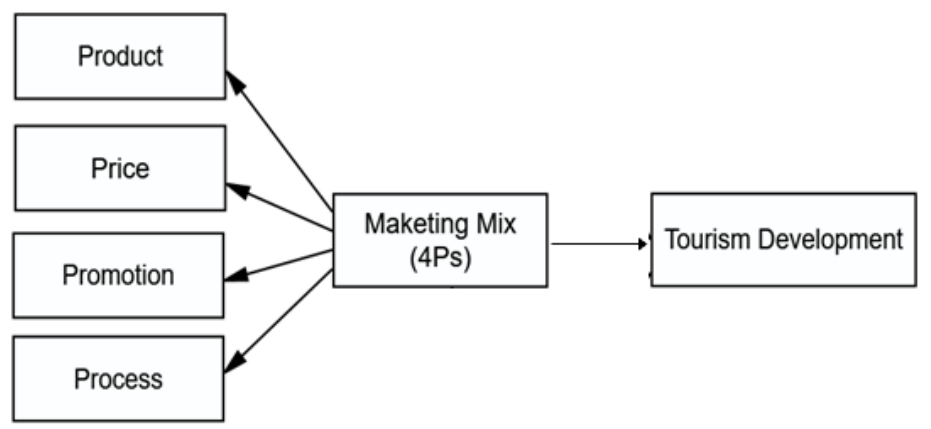

Source: Own study.

\section{Findings and Discussions}

\subsection{Assessment of Measurement Model}

The final measurement model was assessed by using various fit indices quality criteria is required to measure the importance and descriptive strength of measurement model; various quality criteria analyses are conducted to measure the model in this study. To find out the level and trend of relationship between the variables and various factors in the research, a correlation analysis was 
carried out. The basis of identifying the strength of affiliation among the variables was application of "structural model". Various required analyses were carried out by using SPSS 21.0 and Smart-PLS-3. Both EFA and PCA are run via programs like SPSS, which calls this approach data reduction, with the advent of structural equation modelling (SEM) tools, such as PLS, an argument for not purifying measures and treating an instrument more holistically has been made (MacCallum and Austin, 2000, Straub et al., 2004), but there is no clear resolution about whether measurement error should be modelled and accounted for or simply eliminated.

In contrast to EFA, PLS performs a Confirmatory Factor Analysis (CFA) (Gefen and Straub, 2005). As suggested by Zainudin (2012) measurement model was carried out with Confirmatory Factor Analysis (CFA), recommended to remove the items with lower factor loadings which do not meet the minimum threshold. Two questions were dropped in the product mix construct due to lower loadings scores whereas five questions remained for further process. Highest loading score was recorded for "productmix_6, restaurant/food shops are well decorated and have good atmosphere" (0.801), three questions were dropped from price mix construct and four were used for further analysis. Highest lodgings were obtained by "pricemix_2, mountaineering royalty fee is high in CKNP area" (0.889). For the promotion mix, two questions were dropped, and five questions were remained where the highest loading was attained by "contacting with tourist agencies for CKNP area is convenient and fast, promotionmix_4" $(0.88)$ and three questions were dropped and fours were used for the analysis in the process mix, highest loadings was obtained by "you get good service from the tour guide or tourism officials processmix_5" (0.802). Thus, the aim of this model is to find the relationship between marketing mix and tourism development in a selected protected area at Gilgit-Baltistan, Pakistan.

\subsection{Reliability Assessment for the Measurement Model}

To test the measurement model in this study, reliability and validity analyses were carried out which are shown in the Table 1. Results show that Cronbach's alpha, Composite Reliability (CR) and Average Variance Extracted (AVE) are above than the threshold values; "Cronbach's $\alpha:>0.7$ "; (Nunnally and Bernstein, 1978; "> 0.4 (Peter, 1997)", "Composite Reliability :> 0.7” (Hulland, 1999), "Average Variance Extracted (AVE): $>0.5$ " (Khoshkam, 2013; Karim et al., 2021).

\subsection{Internal Reliability}

The key constructs of the tourism marketing mix, 'product mid' had a Cronbach's alpha value of 0.818 , followed by 0.812 for 'price mix', 0.789 for 'process mix' and 0.879 for 'promotion mix'. From the results shown for 
internal reliability, it can be safe to claim that questionnaire used for this study is internally consistent and suitable for the analysis.

\subsection{Composite Reliability}

According to Morrison et al. (2017) "composite reliability can be viewed as analogous of Cronbach's alpha coefficient" which indicates the internal consistency and authenticity of the latent variables. As recommended by Shaw and Shiu (2003) "the threshold value for composite reliability is $\geq 0.60$ " and acceptable values are 0.70 . This study achieved the required acceptable values of composite reliability for its measurement model with the attained tested values as; 'product mix' 0.873 , followed by 0.878 for 'price mix', 0.873 for 'process mix' and 0.879 for 'promotion mix'.

\subsection{Average Variance Extracted (AVE)}

The study obtained the required acceptable values " $>.50$ " of Average Variance Extracted (AVE) for each construct in the measurement model with the attained tested values as; 'product mix' 0.581 , followed by 0.645 for 'price mix', 0.612 for 'process mix' and 0.677 for 'promotion mix'.

\subsection{Convergent Validity}

According to Hair et al. (2014) convergent validity is the "extent to which indicators of a specific construct converge or share high proportion of variance in common". To evaluate the level of convergent validity, three techniques are used as highlighted by Hair et al. (2014), reliability, factor loadings and Average Variance Extracted (AVE). Kline (2011) recommends that AVE value 0.5 or greater is acceptable threshold for adequate convergent validity. In this study 4Ps of marketing mix and tourism development are assessed by using the recommended criteria. Estimated values of each construct in this study meets the rule of thumb and scored more than 0.5 for each construct. The composite reliability values are also given in Table 1 showing that the obtained value for each construct is greater than the threshold minimum score of 0.7 with the range of 0.789 to 0.879 .

Table 1. Results of Quality Criteria

\begin{tabular}{|l|l|l|l|}
\hline Construct & $\begin{array}{l}\text { Cronbach's } \\
\text { Alpha }\end{array}$ & $\begin{array}{l}\text { Composite } \\
\text { Reliability }\end{array}$ & $\begin{array}{l}\text { Average Variance } \\
\text { Extracted (AVE) }\end{array}$ \\
\hline Price Mix & 0.812 & 0.878 & 0.645 \\
\hline Process Mix & 0.789 & 0.863 & 0.612 \\
\hline Product Mix & 0.818 & 0.873 & 0.581 \\
\hline Promotion Mix & 0.879 & 0.912 & 0.677 \\
\hline Tourism Development & - & - & - \\
\hline
\end{tabular}

Source: Own study. 


\subsection{Structural Model Evaluation}

Once the validity and reliability of measurement model get finalised then next steps start to evaluate the structural model outputs. "The coefficient of determination $\left(\mathrm{R}^{2}\right)$, Path coefficient ( $b$ value), and T-statistic value, Effect size $\left(f^{2}\right)$, the Predictive relevance of the model $\left(\mathrm{Q}^{2}\right)$, and Goodness-of-Fit (GOF) index" (Hussain et al., 2018) are the vital criterions to assess the structural model. According to Fornell and Bookstein (1982) " $R$ ' test for dependent variables, the predictive relevance of the model $\left(Q^{2)}\right.$ and effect size $\left(f^{2}\right)$ " (Khoshkam, 2013) scores describes the effeteness of the model used where the values of " $\mathrm{R}^{2}>0.75$ " are substantial, " 0.50 " is mild and "0.26" is frail (Hussain et al., 2018).

The value of variance of endogenous construct obtained for this study shown as $\mathrm{R}^{2}=.346$ predicts a moderate effect of four exogenous variables; (P1-product mix, $\mathrm{P} 2$-price mix, P3-promotion mix, P4-process mix) on endogenous vatable (Tourism Development), $34.60 \%$ of change in tourism development occurs due the given variables. The blindfolding results highlighted below (Table 3) shows acceptable values of $\mathrm{Q}^{2}$ which are greater than the threshold value zero (Khoshkam, 2013) whereas Goodness of Fit (GOF) index is also moderately acceptable with the value of .346 , concluding that the model is having suitable predictive relevance in this study. Moreover, obtained value 0.075 of SRMR (saturated and estimated) indicate that lie below the thresholds value of < 0.08 ( Hu and Bentler, 1999; Cheah et al., 2018) (Table 2).

Table 2. Model fit

Source: Own study.

\begin{tabular}{|l|l|}
\hline SRMR & 0.075 \\
\hline d_ULS & 4.630 \\
\hline d_G & 3.583 \\
\hline Chi-Square & $7,644.858$ \\
\hline NFI & 0.619 \\
\hline
\end{tabular}

Table 3. Construct Cross-validated Communality Test

Source: Own study.

\begin{tabular}{|l|l|l|}
\hline & $\mathrm{Q}^{2}$ & $\mathrm{R}^{2}$ \\
\hline Access & 0.406 & - \\
\hline Accommodation & 0.354 & - \\
\hline Amenities & 0.371 & - \\
\hline Attractions & 0.495 & - \\
\hline Tourism Development & 0.503 & 0.346 \\
\hline
\end{tabular}

\subsection{Overall Final Measurement Model}

As reflected the bootstrapping results in Figure 1, under the variables of marketing mix (4Ps) two variables product mix and process mix were found 
significant with the obtained values of $\beta=-0.197$, standard deviation $=0.066$, t.statictics $=2.970$ and p.value $=<0.05$ and $\beta=-0.139$, standard deviation $=$ 0.042 , t.statictics $=3.308$ and p.value $=<0.05$ respectively. Whereas two variable price mix and promotion mix found insignificant in terms of relations with tourism development. Results shown that $\beta=-0.008$, standard deviation $=$ 0.064 , t.statictics $=0.121$ and p.value $=>0.05$ and $\beta=-0.051$, standard deviation $=0.060$, t.statictics $=0.846$ and p.value $=>0.05$ respectively.

Figure 1. The bootstrapping Results

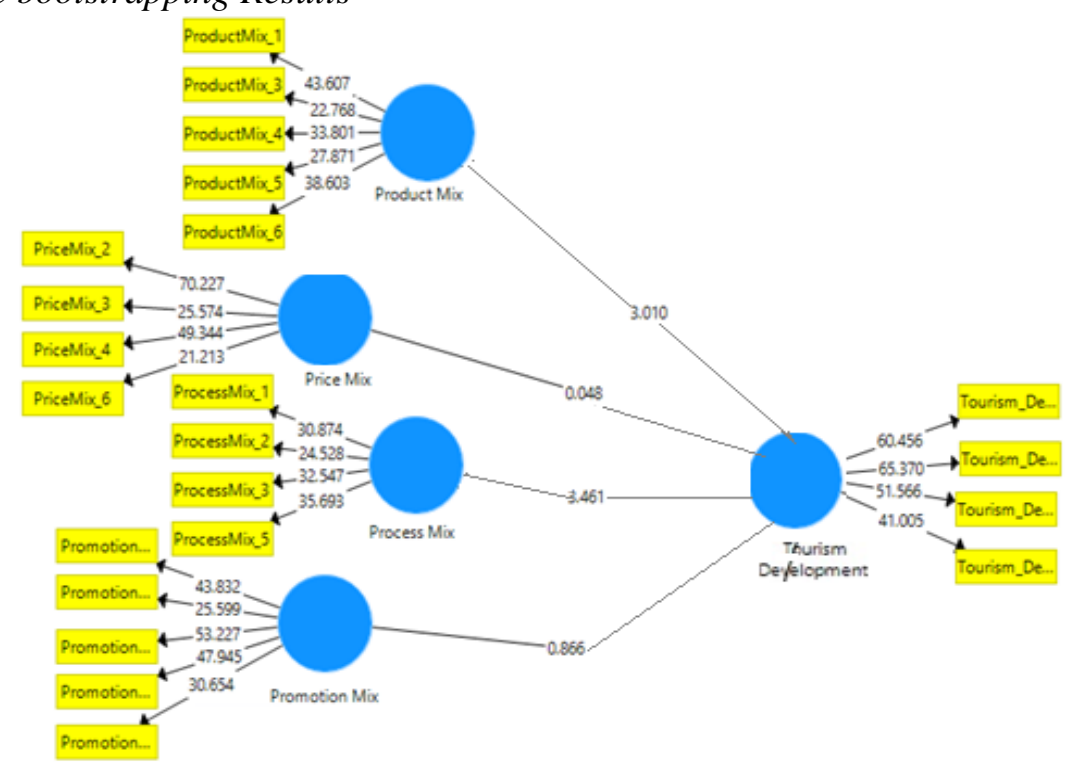

Source: Own study.

\subsection{Hypothesis Testing}

This study model has four (4) latent constructs, product, price, process and promotion. These constructs provide hypotheses to be tested for deducing the empirical association between variables. To test the hypotheses of the study Structural Equation Modelling (SEM) was applied by using Smart PLS-3. Four direct hypotheses through path analysis were carried out on observed variables in this research with following paths;

H1: There is significant effect of product mix on tourism development in CKNP;

H2: There is significant effect of price mix on tourism development in CKNP;

H3: There is significant effect of process mix on tourism development in the CKNP;

H4: There is significant effect of promotion mix on tourism development in the CKNP; 
In addition to testing the hypotheses, the effect size of the marketing mix and tourism supply components were also computed as part of the analysis to validate the objectivity of the study in terms of finding the relationship between the variables. The $\mathrm{f}^{2}$ is level of effect of the latent construct of exogenous variables on latent construct of endogenous variables, meaning that if any construct from exogenous variables is removed whether it effect on endogenous variables. According to Cohen (1988), " $\mathrm{f}^{2}$ values of $0.02,0.15$, and 0.35 considered to be small, medium and signify respectively" (Hussain et al., 2018), given the results in Table 4 all the effects are found non-significant in this study.

Table 4. Path Coefficient and Effect Size $\left(f^{2}\right)$ Results

\begin{tabular}{|l|l|l|}
\hline & path coefficient $(\boldsymbol{\beta})$ & $\mathbf{f}^{\mathbf{2}}$ \\
\hline Price Mix -----> Tourism Development & 0.008 & 0.000 \\
\hline Process Mix ----> Tourism Development & -0.139 & 0.020 \\
\hline Product Mix -----> Tourism Development & -0.197 & 0.020 \\
\hline Promotion Mix -----> Tourism Development & -0.051 & 0.001 \\
\hline
\end{tabular}

Source: Own study.

Based on the statistical evidence, it was revealed product mix and process mix plays role in tourism development. The summary of hypotheses shown in the Table 5 highlighted that two hypotheses were found significant, and two hypotheses were not supported.

Table 5. Hypothesis Results

\begin{tabular}{|l|l|l|l|l|l|l|}
\hline Path & $\begin{array}{l}\text { path } \\
\text { coefficient } \\
(\beta)\end{array}$ & SD & t. stats & P-value & Results & Decision \\
\hline $\begin{array}{l}\text { Product Mix -> } \\
\text { Tourism Development }\end{array}$ & -0.197 & 0.066 & 2.970 & $0.003 * *$ & significant & supported \\
\hline $\begin{array}{l}\text { Price Mix -> Tourism } \\
\text { Development }\end{array}$ & 0.008 & 0.064 & 0.121 & 0.904 & $\begin{array}{l}\text { Not } \\
\text { significant }\end{array}$ & $\begin{array}{l}\text { Not } \\
\text { supported }\end{array}$ \\
\hline $\begin{array}{l}\text { Process Mix -> } \\
\text { Tourism Development }\end{array}$ & -0.139 & 0.042 & 3.308 & $0.001 *$ & significant & supported \\
\hline $\begin{array}{l}\text { Promotion Mix -> } \\
\text { Tourism Development }\end{array}$ & -0.051 & 0.060 & 0.846 & 0.398 & $\begin{array}{l}\text { Not } \\
\text { significant }\end{array}$ & $\begin{array}{l}\text { Not } \\
\text { supported }\end{array}$ \\
\hline
\end{tabular}

Source: Own study.

\section{Conclusions}

The aim of this study was to assess the relationship between tourism marketing mix, 4Ps (product, price, process, and promotion) and tourism development. This assessment was carried out by distributing 509 questionnaires to foreign and domestic tourists who visited CKNP region. Four research questions were created 
for proceed with objective one which are as follows; RQ1: do the product mix of marketing impact the tourism development in the Central Karakoram National Park? RQ2: how prices of travel to Central Karakoram National Park impact the tourism development? RQ3: does process of getting to the Central Karakoram National Park is appropriate which can impact tourism development? and RQ4: how promotion is carried out to develop tourism in the CKNP? Four hypotheses were developed to authenticate the results attained from level of significance $p$ values for the entire variables included in 4Ps of tourism marketing mix.

Al-Azzam (2016) found out the impact of marketing mix on attraction of medical tourism by assessing the responses of international tourists who visited Jordon. Kamua et al. (2015) also attempted to develop model on relationship between marketing mix and domestic tourists' choice of accommodation and destination. This study also highlighted the importance of marketing mix to be understood by the tourism planners for attracting more domestic tourists to the destinations, if blended and conceptualized the required marketing mix factors it will simultaneously increase the demand for tourism.

Results revealed that product mix and process mix showed a significant relationship with tourism development. So, the key findings of this study regarding product mix and process mix are consistent with the studies conducted by Al-Azaam (2016) and Kamua et al. (2015) and price mix and promotion mix is in contrast of these showing insignificant relationship with tourism development in the Central Karakoram National which is in contrast of the findings of Al-Azaam (2016). It is evidence from the results that tourists are not concerned about the expenses which include mountaineering royalty fee, trekking royalty fee and other expenses while they tour to CKNP, therefore, it can be argued that price becomes least important for tourists to be considered therefore, the relationship of price mix with the tourism development is insignificant.

Another argument may come up regarding promotion mix is that traditional advertisements have become obsolete now and majority of tourists use social media as it is also evidenced in the study that majority of tourists get information from social media sources therefore, traditional promotion mix has no influence on attracting tourist towards the destinations. Hence the relationship between promotion mixes and tourism development is insignificant in this study.

\section{References:}

Al-Azzam, A.F.M. 2016. A Study of the Impact of Marketing Mix for Attracting Medical Tourism in Jordan. International Journal of Marketing Studies, 8(1) 139-149.

Armstrong, G., Kotler, P. 2006. Marketing: An introduction (8th ed.). New York: Prentice Hall. 
Avraham. A., Ketter. E., McMillan, P. 2016. Tourism marketing for Developing Countries: Battling Stereotypes and crises in Asia, Africa, and the Middle East. Annals of Tourism Research, 60, 169-187.

Bessom R.M., Jackson, D.W. 1975. Service Retailing: A Strategic Marketing Approach. Journal of Retailing, Summer, p. 84.

Blois, K.J. 1974. The Marketing of Services: An Approach. European Journal of Marketing, Vol. 8, nr 2, 137-145.

Borden, N.H. 1984. The concept of marketing mix. Journal of Advertising Research, 1(9), 2 7.

Branton, N. 1969. The Marketing of Services. Marketing World, Vol. 1, No. 2.

Cheah, J.H., Memon, M.A., Chuah, F., Ting, H., Ramayah, T. 2018. Assessing Reflective Models in Marketing Research: A Comparison Between PLS and PLSC Estimates. International Journal of Business and Society, Vol. 19, No. 1, 139-160.

Coviello, N.E., Brodie, R.J., Munro, H.J. 2000. An investigation of marketing practice by firm size, Journal of Business Venturing, Vol. 15, 523-545.

Constantinides, E. 2006. The Marketing Mix Revisited: Towards the 21st Century Marketing. Journal of Marketing Management, 22, 407-438.

Donohoe, M.H. 2012. Sustainable heritage tourism marketing and Canadas Rideau canal world heritage site. Journal of Sustainable Tourism, Vol. 20, No.1, 121-142, Routledge,

Ferrell, O.C., Hartline, M.D. 2005. Marketing strategy (3rd ed.). Mason, Ohio: SouthWestern Thomson.

Gefen, D., Straub, D. 2005. A practical guide to factorial validity using PLS-Graph: Tutorial and annotated example. Communications of the Association for Information systems, 16 (1), 5 .

Grönroos, C. 1994. Quo Vadis, Marketing? Toward a Relationship Marketing Paradigm. Journal of Marketing Management, Vol. 10, 347-360.

Hair, J.F., Sarstedt, M., Ringle, C.M., Mena, J.A. 2012. An Assessment of the Use of Partial Least Squares Structural Equation Modelling in Marketing Research. J. Acad. Mark. Sci., (40), 414-433.

Hair, J.F., Sarstedt, M., Hopkins, L., Kuppelwieser, V.G. 2014. Partial least squares structural equation modeling (PLS-SEM): An emerging tool in business research. European Business Review, Vol. 26, No. 2, 106-121.

Hinch. D.T., Higham, S.E.J., Moyole, D.B. 2016. Sport tourism and Sustainable destinations: foundations and pathways. Journal of Sport \& Tourism, 20, 3-4,163-173, Routledge.

Hirankitti, P., Mechinda, P., Manjing, S. 2009. Marketing strategies of Thai spa operators in bangkok metropolitan. International Conference on Applied Business Research ICABR Valletta (St. Julians), Malta.

Hussain, S., Fangwei, Z., Siddiqi, A.F., Ali, Z., Shabbir, M.S. 2018. Structural Equation Model for Evaluating Factors Affecting Quality of Social Infrastructure Projects. Sustainability, 10(2-25).

Hu, Y., Ritchie, B. 1999. Measuring destination attractiveness: A contextual approach. Journal of Travel Research, 25-34.

Jamal, T., Camargo, A.B. 2014. Sustainable Justice and an ethic of care: towards the just Destination. Journal of Sustainable Tourism, Vol. 22, No. 1, 11-30, Routledge.

Jobber, D. 2001. Principles and Practice of Marketing, Third edition. McGraw Hill.

Kamau, F., Waweru, F.K., Lewa, P., Misiko, A.J. 2015. The Effects of the Marketing Mix on Choice of Tourist Accommodation by Domestic Tourists in Kenya. International Journal of Novel Research in Marketing Management and Economics, Vol. 2, Issue 2, 25-34. 
Karim, R., Latip, N.A., Marzuki, A., Shah, A., Muhammad, F. 2021. Impact of Supply Components - 4As on Tourism Development: Case of Central Karakoram National Park, Gilgit-Baltistan, Pakistan. International Journal of Economics and Business Administration, 9(1), 411-424.

Khoshkam, M. 2013. Residents' Attitude Towards Impacts from Tourism Development in Anzali Wetland, Iran. PhD., Thesis, Univeristi Sains Malaysia.

Kotler, P., Armstrong, G., Saunders, J., Wong, V. 2001. Principles of Marketing, Third European Edition. Prentice Hall, Pearson Education Limited.

Kotler, P., Armstrong, G., Wong, V., Saunders, J. 2008. Principles of marketing, 5th ed. Financial Times/Prentice Hall.

Lei, W., Kostopoulou, S., Huibin, Y. 2014. The relation of Destination Marketing and Destination Management from a Theoretical Perspective. International Conference on International Business, ICIB.

Liu, S.C., Chou, S. 2016. Tourism Strategy Development and facilitation of integrative processes among brand equity, Marketing and Motivation. Tourism Management, 54, 298-308, Elsevier.

Lovelock, C.H., Patterson, P.G., Walker, R.H. 1998. Service marketing. Australia and New Zealand. New York: Prentice Hall.

Lovelock, C., Wright, L. 2002. Principles of service marketing and management. USA: Prentice Hall.

Lynch, R. 2000. Corporate Strategy 2nd ed. London: Prentice Hall.

Mehrdad, A., Firozeh, H., Negar, J. 2011. The Impact of Web-Marketing Mix (4s) on Development of Tourism Industry in Iran. International Journal of Business and Social Science, 2(6), 267-274.

MacCallum, R.C., Austin, J.T. 2000. Applications of Structural Equation Modelling in Psychological Research. Annual Review of Psychology, 51(1), 201-226.

Morrison, T.G. Morrison, M.A., McCutcheon, J.M. 2017. Best Practice Recommendations for Using Structural Equation Modelling in Psychological Research. Psychology, (8), 1326-1341.

Muala, A.A., Qurneh, M.A. 2012. Assessing the Relationship between Marketing Mix and Loyalty through Tourists Satisfaction in Jordan Curative Tourism. American Academic \& Scholarly Research Journal, Vol. 4, No. 2.

Munusamy, J., Hoo, W.C. 2008. Relationship between marketing mix strategy and consumer motive: An empirical study in major TESCO stores. Unitar E-Journal, 4(2),41-56.

Mwinuka, O.H. 2017. Reviewing the role of tourism marketing in successful sustainable tourist destinations. African Journal of Hospitality, Tourism and Leisure, 6(2), 1-11.

Oh, H. 2000. Diners' perceptions of quality, value, and satisfaction. Cornell Hotel and Restaurant Administration Quarterly, 41(3), 58-66.

Parasuraman, A., Grewal, D. 2000. The impact of technology on the quality- value loyalty chain: A research agenda. Journal of the Academy of Marketing Science, 28(1), 168174.

Patalkova, J. 2012. Travel and Tourism Marketing-Review. Czech Journal of Tourism, (1), 30-52.

Peter, P.J., Donnelly, J.H. 2007. Marketing management: Knowledge and skills, 8th ed. New York: McGraw-Hill.

Pomering, A., Noble, G., Johnson, L.W. 2011. Conceptualizing a contemporary marketing mix for sustainable tourism. Journal of Sustainable Tourism, Vol. 19, No. 8, 953-969.

Romano, C., Ratnatunga, J. 1996. The Role of Marketing. European Journal of Marketing, 29 (7), 9-30. 
Sharma, M., Hazarika, D.D. 2017. Tourism Marketing in India: A Case Study. Pacific Business Review International, 10(5), 83-91.

Shaw, D., Shiu, E. 2003. Ethics in consumer choice: a multivariate modelling approach. European Journal of Marketing, 3710, 1485-1498.

Shostack, G.L. 1977. Breaking Free from Product Marketing. Journal of Marketing, Vol. 41, nr 2.

Sriram, V., Sapienza, H.J. 1991. An empirical investigation of the role of marketing for small exporters. Journal of Small Business Management, 29(4), 33-43.

Stremersch, S., Tellis, G.J. 2002. Strategic Building of Products and Prices: A New Synthesis for Marketing. Journal of Marketing, 66(1), 55-72.

Straub, D., Boudreau, M.C., Gefen, D. 2004. Validation Guidelines for IS Positivist Research. Communications of the Association for Information Systems, 13(24).

Wilson, A. 1972. The Marketing of Professional Services. McGraw-Hill, New York.

Weaver, D., Lawton, L. 2010. Tourism management, 4th ed. Milton, Queensland: John Wiley.

Wijayanti. A., Dewi, I.J. 2016. Analysis of The Four Pillars of Tourism Development Planning in The Tourism Areas of Kretek, Bantul, Yogyakarta, Indonesia. The 12th Biennial Conference of Hospitality and Tourism Industry in Asia (ATF-16), 154-158.

Yeshin, T. 1998. Integrated Marketing Communication, 1st Ed. Butterworth Heinemann.

Zeithaml, V.A. 1981. How consumer evaluation processes differ between goods and service Paper presented at the National Service Conference ED. American Marketing Association, Chicago.

Zeithaml, V., Bitner, M.J., Gremler, D.D. 2006. Services marketing, integrating customer focus across the firm. New York: McGraw-Hill.

Zainudin, A. 2012. Structural Equation Modelling using AMOS Grapics, $2^{\text {nd }}$ Edition. Shah Alam. Universiti Teknologi MARA Publication Centre. 